\title{
ANALISA PENGARUH TUNDA JUAL GABAH KERING PANEN TERHADAP PENDAPATAN PETANI PADI DI DESA KARANG BINANGUN BELITANG MADANG RAYA OKU TIMUR
}

\author{
Munsiarum \\ Sekolah Tinggi Ilmu Pertanian Belitang \\ Jln.Kampus Pertanian No.3 Belitang Kab.OKU Timur Prov.Sumatera Selatan \\ e-mail: Munsiarumatmo77@gmail.com
}

\begin{abstract}
Abstrak
The purpose of this study is to determine the amount of income obtained by farmers who sell grain directly after harvest and farmers who delay selling grain and to find out the difference in income of farmers who sell unhulled grain directly after harvest with farmers who delay selling grain. This research was conducted using a survey method. Sampling of farmers who postpone selling grain and storing them waiting until the price of grain is high was carried out by using the census method for all populations totaling 17. Meanwhile, sampling of farmers who directly sell grain to 17 farmers from 374 populations was carried out using purposive sampling method with criteria respondents are farmers who have their own land with a land area of $>0.5 \mathrm{Ha}$. The results showed that the average production cost for the farmers to postpone selling GKP was IDR 12,911,329 / Ha / MT, the income was IDR 23,215,058 / Ha / MT, so that the income was IDR 10.303,729 / Ha / MT The production costs for direct selling GKP farmers are IDR 12,107,847 / Ha / MT, revenue is IDR 21,527,265 / Ha / MT, so you get an income of IDR 9,419,417 / Ha / MT. The average income of the respondent's delay in selling GKP was higher than that of the respondent who was selling GKP directly with the average difference in income of IDR 884,312 / Ha / MT. The R-C value of the delay in selling GKP is 1.80, while the direct selling value is 1.78. Statistically, there is a significant (significant) difference between the income of the respondent with the delay in selling GKP and the respondent from selling GKP directly. This can be seen from the tvalue of 3.42 and the $t$ value of 2.036 .
\end{abstract}

\section{PENDAhuluan}

Pertanian merupakan sumber kehidupan bagi sebagian besar penduduk negara berkembang seperti Indonesia. Padi merupakan produk pertanian pangan yang utama dalam upaya pemenuhan kebutuhan pangan nasional dan memberikan lapangan pekerjaan bagi sebagian besar penduduk Indonesia. Beberapa faktor yang menyebabkan pentingnya keberadaan padi di Indonesia diantaranya : (1) proses produksi beras menyediakan kesempatan kerja bagi puluhan juta keluarga petani, (2) beras merupakan bahan pangan pokok bagi sekitar $95 \%$ penduduk Indonesia, dan (3) sekitar $30 \%$ dari total pengeluaran rumah tangga miskin dialokasikan untuk membeli beras (Suryana et al, 2001).

Berdasarkan sasaran utama pembangunan pertanian terdapat tiga program pembangunan pertanian yaitu program peningkatan ketahanan pangan, pengembangan agribisnis dan peningkatan kesejahteraan petani. Peningkatan produksi padi ternyata belum mampu meningkatkan kesejahteraan petani. Sekitar 56,5\% petani padi di Indonesia merupakan petani gurem. Penguasaan lahan usahatani padi oleh petani Indonesia rata-rata kurang dari 0,5 hektar, sehingga petani padi Indonesia digolongkan ke dalam kelompok masyarakat miskin (Sensus Pertanian, 2003). Kondisi ini ditambah dengan keterbatasan petani dalam mengakses berbagai layanan seperti pembiayaan usahatani serta sulitnya pemasaran produk panen petani.

Dalam sistem agribisnis padi, pada umumnya petani padi menjual gabah secara langsung kepada penjual besar atau 
tengkulak pada saat musim panen. Sebagian besar petani tidak mempunyai bangunan dan alat penyimpanan serta penggilingan padi sehingga proses tersebut dilakukan oleh pedagang besar. Ketika harga beras naik, maka pedagang-pedagang beras akan menikmati keuntungan dari kenaikan harga

Peningkatan produksi padi, selain untuk menjamin adanya stok pangan (beras) nasional, juga merupakan salah satu upaya untuk menaikkan pendapatan/ kesejahteraan petani dan keluarganya. Namun peningkatan produksi yang dicapai petani pada panen raya, pada kenyataannya belum membawa petani pada peningkatan pendapatan dan kesejahteraan tersebut. Sesuai dengan pola produksi tahunan, produksi gabah pada saat panen raya di daerah sentra produksi selalu melimpah, sedangkan permintaan gabah atau beras bulanan relatif stabil, mengikuti hukum ekonomi, dimana penawaran meningkat permintaan akan menurun, maka demikian juga yang dialami petani pada musim panen raya, dimana harga gabah turun sampai dibawah harga dasar bahkan sampai titik terendah, sehingga tidak memberi keuntungan kepada petani. Sebaliknya pada musim paceklik, sering kali produksi yang tersedia tidak mencukupi kebutuhan sehingga harganya meningkat, bahkan sampai tidak terjangkau oleh petani yang pada saat itu justru tidak memiliki lagi produksi gabah (Gunawan, 2004).

Kesejahteraan petani yang menjadi sasaran pembangunan pertanian perlu diperhatikan lebih serius. Petani sebagai pelaku yang berperan dalam meningkatkan produksi seharusnya mendapatkan perhatian terutama dari pemerintah. Petani selalu menjadi pihak yang dirugikan, dengan biaya produksi yang tinggi, tetapi tidak diimbangi dengan harga jual hasil panen yang tinggi sehingga pendapatan petani tidak meningkat atau bahkan tidak cukup untuk kebutuhan hidup sehari-hari mereka.

Pemerintah berusaha menolong petani dengan berbagai instrumen kebijakan. Salah satu kebijakan tersebut adalah dengan menetapkan Harga Pembelian Pemerintah (HPP) nasional terhadap gabah yang dulu dikenal dengan Harga Dasar Gabah (HDG). Perubahan HDG menjadi HPP sangat mendasar karena dengan kebijakan HPP, pemerintah tidak lagi berkewajiban dan tanggung jawab formal dan juridis untuk menjamin harga dasar gabah pada tingkat harga tertentu, serta bukan menjamin harga beras tersebut. Kondisi tersebut sangat menyulitkan petani terutama pada musim panen karena harga gabah yang sering anjlok. Ditambah lagi dengan masuknya beras impor yang menyebabkan harga beras dalam negeri turun dan semakin terpuruknya kondisi petani (Rachmat, 2000) dasar gabah minimum di tingkat petani (Femina, 2006).

Pemerintah selain menetapkan kebijakan HPP juga memberikan Dana Penguatan Modal Lembaga Usaha Ekonomi Pedesaan (DPM-LUEP) untuk menolong petani, yang merupakan kegiatan yang dilakukan oleh Departemen Pertanian dalam rangka stabilisasi harga gabah terutama pada saat panen raya. Kegiatan ini dilaksanakan dalam bentuk pemberian dana talangan kepada LUEP untuk meningkatkan kemampuannya dalam membeli gabah/beras petani, dengan harga yang wajar dan mengacu pada HPP (Femina, 2006).

Penetapan Harga Pembelian pemerintah (HPP) Nasional yang berlaku untuk semua wilayah Indonesia ditetapkan melalui Inpres No 3 tahun 2007. Petani merasa kebijakan tersebut kurang memberikan motivasi dalam melakukan kegiatan produksi, hal itu disebabkan karena biaya produksi masih tinggi padahal besaran biaya produksi untuk setiap daerah berbedabeda, harga jual gabah pada saat panen dianggap masih rendah dan informasi mengenai HPP tidak sampai kepada petani, sehingga penetapan HPP nasional terkadang kurang memberikan solusi yang berarti (Yulisa, 2008).

Kabupaten OKU Timur sebagai daerah yang memiliki potensi besar pada sektor primer pertanian dan perkebunan, memiliki perkembangan jumlah produksi pertanian yang terus meningkat. Pada tahun 2011 luas lahan panen padi sawah mencapai 138.504 ha, dan menghasilkan produksi Gabah Kering Panen sebesar 886.125 ton, dengan tingkat rata-rata produksi 6,4 Ton / $\mathrm{Ha}$, selanjutnya luas lahan panen padi ladang mencapai 3.312 ha dan menghasilkan produksi Gabah Kering Panen sebesar 10.525 Ton dengan rata-rata produksinya 3.1 ton/ha ( Dinas Tanaman Pangan dan Hortikultura, 2011).

Hasil survei di Desa Karang Binangun Kecamatan Belitang Madang Raya saat ini masih banyak petani yang menjual gabahnya seketika setelah panen selesai dilakukan. Hal ini sebagai akibat dari 
petani yang membutuhkan uang tunai untuk keperluan hidup sehari-hari, bahkan ada yang sudah lebih dahulu meminjam uang kepada tengkulak sebelum panen tiba sehingga pada saat panen petani harus segera membayar hutangnya dengan menjual gabahnya kepada tengkulak tersebut tanpa memprosesnya terlebih dahulu menjadi beras.

Sebagaian petani juga beralasan bahwa menjual gabah langsung adalah untuk mengefisienkan waktu tanpa repot untuk menjemur gabah sehingga mereka dapat mengerjakan pekerjaan yang lain. Walaupun mayoritas petani di desa tersebut banyak yang melakukan penjualan GKP langsung setelah panen, tetapi ada juga sebagian petani yang tidak langsung menjual gabahnya setelah panen. Mereka menjemur gabahnya kemudian menyimpan gabah tersebut di kotak (lumbung) di rumahnya atau menyimpan/menitipkan gabah tersebut di pabrik. Mereka menyimpan gabah tersebut dengan tujuan untuk menunda penjualan dan menunggu waktu sampai harga gabah atau beras tinggi. Ketika harga gabah/beras tinggi mereka baru menjual gabah atau beras tersebut.

Petani yang melakukan penundaan penjualan GKP mengatakan dengan menunda penjualan GKP maka akan memperoleh selisih harga dan keuntungan yang cukup besar dibandingakan dengan menjual GKP langsung ketika selesai panen. Berdasarkan pernyataan petani tersebut, maka penulis tertarik untuk melaksanakan penelitian dengan topik Analisa Pengaruh Tunda Jual Gabah Kering Panen (GKP) Terhadap Pendapatan Petani Padi di Desa Karang Binangun Kecamatan Belitang Madang Raya Kabupaten OKU Timur.

\section{Rumusan Masalah}

Berdasarkan latar belakang di atas maka permasalahan yang akan dibahas dalam penelitian ini adalah :

1. Berapa besar pendapatan yang diperoleh petani yang menjual gabah langsung setelah panen dan petani yang melakukan tunda jual gabah di Desa Karang Binangun?

2. Bagaimana perbedaan pendapatan petani yang menjual gabah langsung setelah panen dengan petani yang melakukan tunda jual gabah di Desa Karang Binangun?

\section{METODE PENELITIAN}

\section{Tempat dan Waktu}

Penelitian ini telah dilaksanakan di Desa Karang Binangun Kecamatan Belitang Madang Raya Kabupaten OKU Timur. Pemilihan lokasi dilakukan secara sengaja (purposive) dengan pertimbangan di desa tersebut sebagian petaninya ada yang menunda jual Gabah Kering Panen (GKP) hingga harga gabah menjadi tinggi. Penelitian telah dilaksanakan pada Bulan Juni 2020.

\section{Metode Penelitian}

Menurut Sopiah (2010), metode penelitian adalah cara atau prosedur tertentu yang sistematis untuk menyelidiki masalah yang memerlukan jawaban. Metode penelitian yang digunakan dalam penelitian ini adalah metode studi kasus (case study). Menurut Zaini (2012), study kasus merupakan serangkaian kegiatan yang dilakukan dengan sungguh-sungguh dengan penuh perhatian terhadap suatu fenomena aktual yang menjadi fokus perhatian dan tahapan-tahapan analisis masalah secara detail untuk mendiagnosis suatu usaha.

\section{Metode Penarikan Contoh}

Pada penelitian ini, responden yang diambil adalah petani padi yang berada di Desa Karang Binangun Kecamatan Belitang Madang Raya. Jumlah petani responden yaitu sebanyak 34 petani yang terdiri dari 17 petani yang menunda jual gabah dan 17 petani yang langsung menjual gabah ketika selesai panen. Pengambilan sampel petani yang menunda jual gabah dan menyimpannya menunggu hingga harga gabah tinggi padi dilakukan dengan menggunakan metode sensus terhadap semua populasi yang berjumlah 17 petani sehingga semua populasi akan dijadikan sebagai sampel dalam penelitian. Sedangan pengambilan sampel terhadap petani yang langsung menjual gabah terhadap 17 petani dari 374 populasi dilakukan dengan menggunakan metode purposive sampling dengan kriteria responden adalah petani yang memiliki lahan sendiri dengan luas lahan $\geq 0,72 \mathrm{Ha}$ yang tergabung dalam satu kelompok tani. 


\section{Metode Pengumpulan Data}

Data yang digunakan dalam penelitian ini adalah data primer dan data sekunder. Data primer diperoleh melalui wawancara langsung dengan petani padi sawaha yang berada di Desa Karang Binangun yang dipandu dengan kuesioner, sedangkan data sekunder diperoleh dari penelusuran karyakarya ilmiah yang terkait dengan penelitian dan data-data yang diperoleh dari PPL dan profil Desa Karang Binangun serta media komunikasi internet.

\section{Metode Pengolahan dan Analisis Data}

Data yang diperoleh, baik data primer maupun data sekunder dalam penelitian ini akan dianalisis secara kuantitatif. Analisis data yang dilakukan meliputi analisis terhadap biaya-biaya yang dikeluarkan, penerimaan yang diperoleh, pendapatan usahatani padi, analisa R/C Rasio dan uji t. Pengolahan data dilakukan dengan menggunakan bantuan komputer (Microsoft Excel). Untuk menjawab hipotesis yang pertama yaitu bahwa pendapatan petani yang melakukan tunda jual gabah di Desa Karang Binangun lebih besar daripada pendapatan petani yang menjual gabah secara langsung secara matematis dapat dinyatakan sebagai berikut (Soekartawi, 1995) :

1. $\mathrm{TC}=\mathrm{FC}+\mathrm{VC}$

2. $\mathrm{TR}=\mathrm{P} \times \mathrm{Q}$

3. $\mathrm{I}=\mathrm{TR}-\mathrm{TC}$

4. $\mathrm{R} / \mathrm{C}=\frac{\mathrm{TR}}{\mathrm{TC}}$

\footnotetext{
Keterangan

$\mathrm{TC}=$ Total Cost (Biaya Total $)$

$\mathrm{FC}=$ Fixed Cost (Biaya Tetap)

$\mathrm{VC}=$ Variable Cost (Biaya Variabel)

$\mathrm{TR}=$ Total Revenues (Penerimaan)

$\mathrm{P}=$ Price (Harga)

$\mathrm{Q}=$ Quantum (Jumlah produksi)

$\mathrm{I}=$ Income (Pendapatan)

$\mathrm{R} / \mathrm{C}=$ Return Cost Rasio

(Penerimaan/Biaya)

Dengan kriteria :

R/C Ratio > 1 Berarti usahatani menguntungkan

$\mathrm{R} / \mathrm{C}$ Ratio $=1$ Berarti usahatani tidak untung dan tidak rugi (impas)
}

R/C Ratio < 1 Berarti usahatani tidak

menguntungkan (rugi)

Untuk menjawab hipotesis kedua yaitu bahwa terdapat perbedaan pendapatan yang signifikan antara petani yang melakukan tunda jual gabah dengan petani yang menjual gabah secara langsung maka dilakukan uji statistik yaitu dengan uji $\mathrm{t}$ beda rata-rata. Adapun rumus yang digunakan adalah sebagai berikut :

$$
t=\frac{\overline{X_{1}}-\overline{X_{2}}}{\sqrt{\frac{\left(n_{1}-1\right) S_{1}^{2}+\left(n_{2}-1\right) S_{2}^{2}}{n_{1}+n_{2}-2}\left(\frac{1}{n_{1}}+\frac{1}{n_{2}}\right)}}
$$

dimana :

$\mathrm{t}=$ Nilai $\mathrm{t}$

$\mathrm{n}_{1}=$ Jumlah sampel petani tunda jual GKP

$\mathrm{n}_{2}=$ Jumlah sampel petani jual langsung GKP

$\overline{x_{1}}=$ Nilai rata-rata pendapatan tunda jual GKP

$\overline{x_{2}}=$ Nilai rata-rata pendapatan jual langsung GKP

$\mathrm{S}_{1}{ }^{2}=$ Varian sampel ke 1

$\mathrm{S}_{2}{ }^{2}=$ Varian sampel ke 2

Adapun kaidah dari uji t beda rata-rata dalam penelitian ini adalah :

1. Jika t_hit < t tabel maka non significant atau tidak terdapat perbedaan yang signifikan antara pendapatan petani yang melakukan tunda jual gabah dengan pendapatan petani yang melakukan penjualan langsung gabah.

2. Jika t_hit > t_tabel maka significant atau terdapat perbedaan yang nyata (signifikan) antara pendapatan petani yang melakukan tunda jual gabah dengan pendapatan petani yang melakukan penjualan langsung gabah.

\section{HASIL DAN PEMBAHASAN}

\section{Karakteristik Petani Responden}

Sampel yang diambil adalah sebanyak 34 responden yang terdiri dari 17 petani yang melakukan tunda jual GKP dan 17 petani yang menjaul GKP langsung setelah panen di Desa Karang Binangun. Faktor sosial ekonomi dalam kegiatan usahatani padi berpengaruh terhadap keputusan petani dalam aktivitas usahataninya. 


\section{Umur}

Usia kerja adalah suatu tingkat umur seseorang yang diharapkan sudah dapat bekerja dan menghasilkan pendapatannya sendiri. Usia kerja ini berkisar antara 14 sampai 55 tahun. Usia sangat terkait dengan tingkat produktivitas tenaga kerja dalam berusahatani. Seluruh aktivitas usahatani berhubungan dengan tingkat kemampuan fisik, dalam usia produktif tentu akan memiliki tingkat produktivitas yang lebih tinggi dibanding dengan petani-petani yang telah memasuki usia senja.

Tabel 1. Responden Tunda Jual GKP dan Jual Langsung GKP Berdasar

Umur

\begin{tabular}{cccc}
\hline NO & $\begin{array}{l}\text { Umur } \\
\text { (Tahun) }\end{array}$ & $\begin{array}{c}\text { Tunda Jual } \\
\text { GKP } \\
\text { (Orang) }\end{array}$ & $\begin{array}{c}\text { Jual } \\
\text { Langsung } \\
\text { (Orang) }\end{array}$ \\
\hline 1. & $41-50$ & 6 & 4 \\
2. & $51-60$ & 10 & 11 \\
3. & $61-70$ & 1 & 2 \\
4. & $>70$ & - & - \\
\hline & Jumlah & 17 & 17 \\
\hline
\end{tabular}

Berdasarkan data pada Tabel 1, dapat diketahui bahwa sebagian besar responden petani tunda jual GKP dan jual langsung GKP memiliki usia yang berkisar antara 41 hingga 60 tahun. Presentase terbesar terdapat pada petani dengan usia antara 5160 tahun hal ini disebabkan karena pada usia tersebut dominasi adalah kepala keluarga dengan tuntutan untuk memenuhi kebutuhan keluarganya. Petani dengan usia antara 4150 tahun juga cukup banyak, dimana usia produktiv yang paling baik ada pada usia 41 hingga 50, kemudian semakin menurun pada usia hingga di atas 60 tahun. Tidak terdapat responden pada usia antara 31 hingga 40 tahun. Hal ini menunjukkan bahwa mulai menurunnya semangat dari generasi muda untuk mengembangkan kegiatan usahatani di desa tersebut.

\section{Tingkat Pendidikan}

Tingkat pendidikan dari seseorang berpengaruh juga dalam kegiatan usahataninya, dalam hal ini adalah kemampuan dan keterampilan petani dalam menyerap informasi maupun teknologi baru yang berasal dari kelompok maupun pihak penyuluh. Tingkat pendidikan yang rendah akan mengakibatkan kemampuan dan daya serap petani terhadap teknologi dan informasi berupa pengembangan pertanian dan budidaya untuk membantu meningkatkan kesejahteraan petani menjadi semakin lamban. Sedangkan apabila petani memiliki tingkat pendidikan yang tinggi dan cukup baik, dapat menyebabkan petani tersebut mampu untuk menyesuaikan pekerjaannya dengan hasil yang akan diperoleh nantinya.

Tabel 2. Tingkat Pendidikan Responden

\begin{tabular}{llcc}
\hline NO & $\begin{array}{l}\text { Pendidik } \\
\text { an }\end{array}$ & $\begin{array}{c}\text { Tunda Jual } \\
\text { GKP } \\
\text { (Orang) }\end{array}$ & $\begin{array}{c}\text { Jual } \\
\text { Langsung } \\
\text { (Orang) }\end{array}$ \\
\hline 1. & SD & 4 & 8 \\
2. & SMP & 7 & 5 \\
3. & SMA & 7 & 4 \\
4. & Sarjana & 2 & - \\
\hline & Jumlah & 17 & 17 \\
\hline
\end{tabular}

Berdasarkan data pada Tabel 2, dapat dilihat bahwa tingkat pendidikan petani responden di Desa Karang Binangun masih tergolong rendah. Responden tunda jual GKP dengan tingkat pendidikan SD berjumlah 4 orang dan responden jual langsung GKP berjumlah 8 orang. Hal ini disebabkan karena prioritas utama dari responden adalah bekerja dan memperoleh pendapatan dengan memanfaatkan lahan yang ada baik berupa lahan milik sendiri maupun lahan sewa. Responden mengatakan bahwa dalam melakukan kegiatan usahatani yang paling penting adalah pengalaman bukan pendidikan.

\section{Anggota Keluarga yang menjadi \\ Tanggungan}

Jumlah anggota keluarga yang menjadi tanggungan bagi petani akan berpengaruh pada motivasi untuk bekerja dalam kegiatan usahatani untuk dapat meningkatkan kesejahteraan keluarganya dengan tercapainya pemenuhan kebutuhan seharihari. Jumlah anggota keluarga dari responden yang telah didata berkisar antara 2 anggota sampai dengan 6 anggota keluarga.

Tabel 3. Jumlah Anggota Keluarga yang Menjadi Tanggungan.

\begin{tabular}{cccc}
\hline No & $\begin{array}{c}\text { Anggota } \\
\text { Keluarga }\end{array}$ & $\begin{array}{c}\text { Tunda Jual } \\
\text { GKP } \\
\text { (Orang) }\end{array}$ & $\begin{array}{c}\text { Jual } \\
\text { Langsung } \\
\text { (Orang) }\end{array}$ \\
\hline 1. & $1-3$ & 6 & 7 \\
2. & $4-6$ & 11 & 10 \\
\hline & Jumlah & 17 & 17 \\
\hline
\end{tabular}


Berdasarkan data pada Tabel 3 di atas, dapat dilihat bahwa rata-rata petani di Desa Karang Binangun terdiri atas tanggungan keluarga yang terdiri 2 orang tua dan 2-4 orang anak. Dengan adanya jumlah anggota keluarga ini dapat membantu petani yang berperan sebagai kepala keluarga dalam mengelola usahataninya sebagai tenaga kerja dalam keluarga, sehingga dapat mengurangi biaya pengeluaran dan meningkatkan pendapatan petani.

\section{Luas Lahan Pertanian}

Lahan adalah tempat untuk melakukan kegiatan bercocok tanam dan menghasilkan produk pertanian yang diinginkan oleh petani dengan hasil yang dijual kepada konsumen. Desa Karang Binangun, memiliki luasan lahan yang sangat beragam. Dari hasil data menunjukkan rata-rata luas lahan responden tunda jual GKP adalah 0,54 ha dan responden jual langsung rata-rata luas lahan 0,88 ha.

\section{Analisis Biaya Tunda Jual GKP dan Jual Langsung GKP}

Biaya dalam kegiatan usahatani dikeluarkan oleh petani dengan tujuan untuk menghasilkan pendapatan yang tinggi bagi usahatani yang dikerjakan, dengan mengeluarkan biaya maka pertanian mengharapkan pendapatan yang setinggitingginya melalui peningkatan produksi. Biaya dalam kegiatan usahatani terdiri dari biaya tetap (fixed cost) dan biaya variabel (variabel cost).

Biaya tetap (Fixed Cost) adalah biaya yang relatif tetap jumlahnya dan harus dikeluarkan walaupun produk yang dihasilkan banyak atau sedikit. Biaya tidak tetap (Variable cost) adalah biaya yang sifatnya berubah-ubah tergantung dari besar kecilnya produksi yang dihasilkan. Dalam hasil penelitian yang dikelompokkan ke dalam biaya tetap di antaranya adalah biaya sewa lahan dan penyusutan alat. Sedangkan untuk biaya variabel terdiri dari biaya benih, pupuk, pestisida dan biaya tenaga kerja.

Berikut ini merupakan komponen biaya yang dikeluarkan oleh petani responden tunda jual GKP dan jual langsung GKP di Desa Karang Binangun Kecamatan Belitang Madang Raya :

\section{Biaya Tetap (Fix Cost)}

Biaya tetap yang digunakan oleh petani responden tunda jual GKP dan jual langsung GKP di Desa Karang Binangun Kecamatan Belitang Madang Raya diantaranya meliputi biaya sewa lahan dan biaya penyusutan peralatan yang dapat dilihat pada Tabel 4 sebagai berikut :

\section{Tabel 4. Biaya Tetap Petani Tunda Jual} GKP dan Jual Langsung GKP.

\begin{tabular}{|c|c|c|c|c|c|}
\hline \multirow[t]{2}{*}{ No } & \multirow{2}{*}{$\begin{array}{l}\text { Komponen } \\
\text { Biaya }\end{array}$} & \multicolumn{2}{|c|}{ Tunda Jual GKP } & \multicolumn{2}{|c|}{ Jual Langsung GKP } \\
\hline & & $(\mathrm{Rp} / \mathrm{Lg} / \mathrm{MT})$ & $(\mathrm{Rp} / \mathrm{Ha} / \mathrm{MT})$ & $(\mathrm{Rp} / \mathrm{Lg} / \mathrm{MT})$ & $(\mathrm{Rp} / \mathrm{Ha} / \mathrm{MT})$ \\
\hline 1. & $\begin{array}{l}\text { Sewa } \\
\text { Lahan }\end{array}$ & 2.370 .000 & 4.369 .848 & 3.874 .882 & 4.418 .042 \\
\hline 2. & $\begin{array}{l}\text { Penyusutan } \\
\text { Alat }\end{array}$ & 75.459 & 184.296 & 82.032 & 95.935 \\
\hline & Total & 2.445 .459 & 4.546 .061 & 3.956 .915 & 4.516 .523 \\
\hline
\end{tabular}

Kegiatan usahatani padi sawah responden tunda jual GKP dan jual langsung GKP di Desa Karang Binangun Kecamatan Belitang Madang Raya, dalam penggunaan input lahan sebagian besar memiliki status kepemilikan lahan sendiri, namun ada beberapa petani yang memiliki status kepemilikan lahan sewa, sehingga dalam kaidah usahatani semuanya dianggap sebagai lahan sewa. Berdasarkan data di atas bahwa biaya sewa lahan petani tunda jual GKP dengan luas lahan rata-rata $0,54 \mathrm{Ha}$ memerlukan biaya sebesar Rp 2.370 .000 atau sebesar Rp 4.369.848/Ha. Untuk biaya sewa lahan petani jual langsung GKP dengan luas lahan rata-rata $0,88 \mathrm{Ha}$ biaya yang dibutuhkan adalah Rp 3.878.882 atau sebesar Rp 4.418.042/Ha.

Biaya penyusutan peralatan yang dihitung meliputi penyusutan peralatan yang terdiri atas cangkul, sabit, ember, handsprayer dan roli. Biaya rata-rata penyusutan alat yang digunakan oleh responden tunda jual GKP adalah Rp $75.459 / \mathrm{Lg}$ atau $\mathrm{Rp} 184.296 / \mathrm{Ha}$ dan responden jual langsung GKP adalah sebesar $\mathrm{Rp} \mathrm{82.032/Lg} \mathrm{atau} \mathrm{Rp} \mathrm{95.935/Ha.} \mathrm{Jumlah}$ rata-rata biaya tetap responden tunda jual GKP adalah Rp 2.445.459/Lg atau Rp $4.546 .061 / \mathrm{Ha}$ dan rata-rata biaya tetap responden jual langsung GKP adalah Rp 3.956.915/Lg atau Rp 4.516.523/Ha.

\section{Biaya Variabel (Variabel Cost)}

Biaya variabel adalah biaya yang digunakan dalam kegiatan usahatani dan biasanya habis dalam satu kali proses produksi. Biaya variabel yang digunakan dalam usahatani padi sawah di Desa Karang 
Binangun terdiri atas biaya benih, pupuk, pestisida, dan tenaga kerja. Besarnya biaya variabel yang dikeluarkan oleh petani responden dapat dilihat pada Tabel 5 sebagai berikut :

Tabel 5. Rata-rata Biaya Variabel Petani Tunda Jual dan Jual Langsung GKP

\begin{tabular}{|c|c|c|c|c|c|}
\hline \multirow[t]{2}{*}{ No } & \multirow[t]{2}{*}{ Komponen } & \multicolumn{2}{|c|}{ Tunda Jual GKP } & \multicolumn{2}{|c|}{ Jual Langsung GKP } \\
\hline & & (RpplgMI) & (RppHaMT & (RpplgMI) & (RppHaMI \\
\hline & Biaya Saprodi & 864.188 & 1.593 .406 & 1.345 .324 & 1.533 .903 \\
\hline & Tenaga Kerja & 1.3966 .691 & 2.575 .244 & 2.139 .765 & 2.439 .705 \\
\hline & Biaya Karnung & 86.765 & 159.978 & 161.415 & 184.041 \\
\hline & Biaya Panen & 1.931 .110 & 3.5606 .614 & 2999.654 & 3.420 .129 \\
\hline & Jumlah Total & 4.278754 & 7.985 .906 & 6.646 .157 & 7.591 .324 \\
\hline
\end{tabular}

Berdasarkan hasil pada Tabel 5, dapat diketahui bahwa rata-rata penggunaan biaya variabel kegiatan usahatani padi sawah oleh petani yang melakukan tunda jual GKP dan jual langsung GKP di Desa Karang Binangun adalah sebesar Rp 7.985.906/Ha/MT dan $\mathrm{Rp}$ 7.591.324/Ha/MT, dengan biaya terbesar terdapat pada komponen biaya panen. Hal ini disebabkan karena dalam kegiatan panen terdapat beberapa urutan kegiatan diantaranya biaya bawon, biaya konsumsi dan biaya transportasi. Untuk penjelasan secara umum berdasarkan rata-rata masingmasing biaya variabel akan dijelaskan sebagai berikut :

\section{a. Biaya Saprodi}

Penggunaan biaya saprodi dalam kegiatan usahatani padi sawah baik yang dilakukan oleh petani tunda jual GKP dan petani jual langsung GKP diantaranya digunakan untuk biaya benih, biaya pupuk, biaya insectisida dan biaya herbisida. Besarnya biaya saprodi yang dikeluarkan oleh petani yang melakukan tunda jual GKP adalah sebesar Rp 864.188/Lg/MT atau sebesar Rp 1.593.406/Ha/MT. Besarnya biaya saprodi yang dikeluarkan petani yang melakukan jual langsung GKP adalah sebesar Rp 1.345.324/Lg/MT atau sebesar Rp 1.533.903/Ha/MT.

\section{b. Biaya Tenaga Kerja}

Tenaga kerja merupakan salah satu faktor produksi yang memiliki pengaruh besar terhadap biaya usahatani. Oleh karena itu dalam penggunaannya petani harus memperhitungkannya. Kebutuhan tenaga kerja dalam satu musim tanam yang digunakan petani baik yang menunda jual maupun yang menjual langsung di Desa Karang Binangun pada umumnya relatif sama yaitu terdiri dari biaya pengolahan lahan, biaya semai, tanam, penyulaman, penyiangan, pemupukan dan pengendalian OPT.

Adapun besarnya biaya tenaga kerja rata-rata dalam kegiatan usahatani padi di Desa Karang Binangun dalam satu kali musim tanam yang dikeluarkan oleh petani yang melakukan tunda jual GKP dengan luas lahan 0,54 $\mathrm{Ha}$ adalah sebesar $\mathrm{Rp}$. 1.396 .691 atau $\mathrm{Rp} \quad 2.575 .244 / \mathrm{Ha} / \mathrm{MT}$. Sedangkan total biaya tenaga kerja yang dikeluarkan oleh petani yang melakukan jual langsung GKP dengan luas garapan rata-rata 0,88 Ha adalah sebesar Rp 2.139.765/MT atau sebesar Rp 2.439.705/Ha/MT.

\section{c. Biaya Karung}

Penggunaan biaya pembelian karung padi dalam kegiatan usahatani padi sawah baik yang dilakukan oleh petani tunda jual GKP dan petani jual langsung GKP relatif sama. Umumnya karung yang digunakan adalah karung $125 \mathrm{~kg}$. Rata-rata harga karung adalah Rp 55.000/kodi. Besarnya biaya pembelian karung yang dikeluarkan oleh petani yang melakukan tunda jual GKP adalah sebesar Rp 86.765/Lg/MT atau sebesar Rp 159.978/Ha/MT. Besarnya biaya pembelian karung yang dikeluarkan petani yang melakukan jual langsung GKP adalah sebesar Rp 161.415/Lg/MT atau sebesar Rp 184.041/Ha/MT.

\section{d. Biaya Panen}

Kegiatan panen merupakan kegiatan yang membutuhkan jumlah tenaga kerja yang paling banyak dan memerlukan biaya yang paling besar dalam kegiatan usahatani padi di Desa Karang Binangun baik petani padi tunda jual GKP maupun petani padi jual langsung GKP. Biaya panen yang dikeluarkan adalah untuk biaya bawon dengan pembagian 8:1, biaya konsumsi panen dan biaya angkut padi dari sawah ke rumah petani.

Rata-rata jumlah biaya panen yang dikeluarkan oleh petani tunda jual GKP adalah sebesar Rp 1.931.110/Lg/MT atau sebesar Rp 3.560.614/Ha/MT. Rata-rata jumlah biaya panen yang dikeluarkan oleh petani jual langsung GKP adalah sebesar Rp. 2.999.654/LgMT atau sebesar Rp 
3.420.129/Ha/MT. Total biaya variabel yang dikeluarkan petani tunda jual GKP adalah Rp. $4.278 .754 / \mathrm{Lg} / \mathrm{MT}$ atau sebesar Rp 7.985.906/Ha/MT dan total biaya varibel petani jual langsung GKP adalah sebesar Rp. 6.646.157/Lg/MT atau sebesar Rp 7.591.324/Ha/MT.

\section{Biaya Total (Total Cost)}

Biaya total dalam usahatani padi sawah di Desa Karang Binangun terdiri dari biaya tetap ditambah dengan biaya variabel. Dalam satu musim tanam, biaya total yang dikeluarkan responden tunda jual GKP lebih besar dibandingkan biaya total yang dikeluarkan oleh responden jual langsung GKP. Hal ini karena responden tunda jual GKP harus mengeluarkan biaya untuk penanganan pasca panen berupa biaya penjemuran padi. Besarnya biaya total yang dikeluarkan oleh petani padi organik dan anorganik dapat dilihat pada Tabel 6 sebagai berikut :

Tabel 6. Biaya Total Petani Tunda Jual GKP dan Jual Langsung GKP.

\begin{tabular}{|l|l|c|c|c|c|}
\hline No & Komponen & \multicolumn{2}{|c|}{ Tunda Jual GKP } & \multicolumn{2}{c|}{ Jual Langsung GKP } \\
\cline { 3 - 6 } & & Rp LgMT) & (Rp/HaMT) & (Rp LgMT) & (Rp/HaMT) \\
\hline 1. & Biaya Tetap & 2.445 .459 & 4.546 .061 & 3.956 .915 & 4.516 .523 \\
\hline 2. & Biaya Variabel & 4.287 .853 & 8.006 .531 & 6.646 .157 & 7.591 .324 \\
\hline 3 & Biaya Jemur & 173.529 & 323.072 & - & - \\
\hline & Biaya Total & 6.906 .841 & 12.875 .664 & 10.603 .072 & 12.107 .847 \\
\hline
\end{tabular}

Sumber : Data Primer, 2014. (Lampiran 15,18 \& 34)

Berdasarkan hasil pada Tabel 13, dapat diketahui bahwa biaya total produksi petani tunda jual GKP di Desa Karang Binangun dalam satu musim tanam dengan rata-rata luas garapan 0,54 adalah sebesar $\mathrm{Rp} \quad 6.906 .841$ atau sebesar $\mathrm{Rp}$ 12.875.664/Ha/MT. Adapun biaya total produksi petani responden jual langsung GKP dalam satu musim tanam dengan ratarata luas garapan 0,88 $\mathrm{Ha}$ adalah sebesar $\mathrm{Rp}$ 10.603.072 atau sebesar Rp 12.107.847 /Ha/MT. Total biaya produksi petani responden tunda jual GKP dalam satu musim tanam lebih besar dibandingkan total biaya produksi petani responden jual langsung GKP.

\section{Produksi, Harga Jual, Penerimaan dan Pendapatan}

Hasil akhir atau yang lebih dikenal dengan produksi secara teknis adalah sesuatu proses pendayagunaan sumbersumber yang tersedia dengan harapan terwujudnya hasil yang lebih dari segala pengorbanan yang diberikan. Produksi yang dihasilkan oleh petani yang melakukan tunda jual GKP adalah Gabah Kering Giling (GKG). Sedangkan produksi yang dihasilkan oleh petani yang melakukan jual langsung GKP adalah berupa Gabah Kering Panen (GKP).

Tabel 7. Produksi Penerimaan dan Pendapatan Responden Tunda Jual GKP

\begin{tabular}{rlrr}
\hline No & Uraian & \multicolumn{2}{c}{$\begin{array}{c}\text { Nilai(Rp/Lg/MT) } \\
\text { (Rp/Ha/MT) }\end{array}$} \\
\hline 1. & Produksi & 3.425 & 6.343 \\
& GKP $(K g)$ & & \\
2. & $\begin{array}{l}\text { Produksi } \\
\text { GKG (Kg) }\end{array}$ & 3.083 & 5.708 \\
3. & Harga Jual & 4.171 & 4.171 \\
& GKG \\
4. & Penerimaan & 12.843 .505 & 23.801 .633 \\
5. & Biaya Total & 6.733 .312 & 12.559 .592 \\
& (FC + VC) & & \\
6. & Biaya & 173.529 & 323.072 \\
& Jemur & & \\
7. & Biaya Total & 6.906 .841 & 12.875 .664 \\
8. & Pendapatan & 5.936 .664 & 10.925 .969 \\
9. & R/C rasio & 1,85 & 1,85 \\
\hline
\end{tabular}

Sumber : Data Primer, 2014. (Lampiran 19)

Rata-rata produksi Gabah Kering Panen (GKP) yang dihasilkan oleh petani tunda jual GKP dalam usahatani padi sawah dengan luas garapan rata-rata $0,54 \mathrm{Ha}$ adalah $3.425 \mathrm{Kg} / \mathrm{Lg} / \mathrm{MT}$ atau sebesar 6.343 $\mathrm{Kg} / \mathrm{Ha} / \mathrm{MT}$. Setelah dilakukan proses penjemuran dengan penyusutan sebesar ratarata $10 \%$ maka dihasilkan volume Gabah Kering Giling (GKG) sebesar 3.083 $\mathrm{Kg} / \mathrm{Lg} / \mathrm{MT}$ atau sebesar $5.708 \mathrm{Kg} / \mathrm{Ha} / \mathrm{MT}$. Rata-rata harga jual GKG sebesar Rp $4.171 / \mathrm{Kg}$ maka menghasilkan rata-rata penerimaan sebesar Rp 12.843.505/Lg/MT atau penerimaan sebesar $\mathrm{Rp}$ 23.801.633/Ha/MT. Total biaya produksi petani tunda jual GKP ditambah dengan biaya penjemuran adalah sebesar Rp 6.906.841/Lg/MT atau sebesar Rp 12.875.664/Ha/MT sehingga menghasilkan rata-rata pendapatan sebesar $\mathrm{Rp}$ 
5.936.664/Lg/MT atau pendapatan sebesar Rp 10.925.969/Ha/MT

Hasil atau produksi yang dihasilkan oleh petani yang melakukan jual langsung GKP adalah berupa Gabah Kering Panen (GKP). Dalam pelaksanaannya petani setelah panen mereka langsung menjual gabahnya tanpa menyimpannya dan melakukan penjemuran sehingga harganya jatuh. Adapun produksi, harga jual, biaya produksi, penerimaan, pendapatan dan analisa $\mathrm{R} / \mathrm{C}$ rasio petani jual langsung GKP dapat dilihat pada tabel 15 .

Tabel 8. Produksi, Penerimaan dan Pendapatan Responden Jual Langsung GKP

\begin{tabular}{|c|c|c|c|}
\hline \multirow[t]{2}{*}{ No } & \multirow[t]{2}{*}{ Uraian } & \multicolumn{2}{|l|}{ Nilai } \\
\hline & & $(\mathrm{Rp} / \mathrm{Lg} / \mathrm{MT})$ & $(\mathrm{Rp} / \mathrm{Ha} / \mathrm{MT})$ \\
\hline 1. & Produksi & 5.380 & 6.151 \\
\hline & GKP & & 3.500 \\
\hline 2. & Harga Jual & 3.500 & 21.527 .265 \\
\hline & GKP & & 12.107 .847 \\
\hline 3. & Penerimaan & 18.831 .723 & 9.419 .417 \\
\hline 4. & Biaya & 10.603 .072 & 1,78 \\
\hline & Produksi & & \\
\hline 5. & Pendapatan & 8.228 .651 & \\
\hline 6. & $\mathrm{R} / \mathrm{C}$ rasio & 1,78 & \\
\hline
\end{tabular}

Sumber : Data Primer, 2014. (Lampiran 35)

Rata-rata produksi gabah yang dihasilkan oleh petani jual langsung GKP dalam usahatani padi sawah dengan luas lahan rata-rata $0,88 \mathrm{Ha}$ adalah 5.380 $\mathrm{Kg} / \mathrm{Lg} / \mathrm{MT}$ atau $6.151 \mathrm{Kg} / \mathrm{Ha} / \mathrm{MT}$, dengan rata-rata harga jual gabah sebesar $\mathrm{Rp}$ $3.500 / \mathrm{Kg}$ dan menghasilkan rata-rata penerimaan sebesar $18.831 .723 / \mathrm{Lg} / \mathrm{MT}$ atau sebesar Rp 21.527.265/Ha/MT. Total biaya produksi petani jual langsung GKP adalah sebesar Rp 10.603.072/Lg/MT atau sebesar Rp 12.107.847. Rata-rata pendapatan sebesar Rp 8.228.651/Lg/MT atau sebesar Rp 9.419.417/Ha/MT.

Berdasarkan uraian di atas menunjukkan bahwa dalam melakukan usahatani padi sawah pendapatan yang diperoleh dari responden tunda jual GKP dan menjual produknya dalam bentuk Gabah Kering Giling (GKG) yaitu sebesar Rp 10.925.969/Ha/MT atau Rp $1.914 / \mathrm{Kg}$, dan pendapatan yang diperoleh dari responden jual langsung GKP dan menjual usahataninya dalam bentuk gabah kering panen (GKP) adalah sebesar Rp 9.419.417/Ha/MT atau Rp $1.531 / \mathrm{Kg}$. Hal ini ini menunjukan pendapatan petani tunda jual GKP lebih besar daripada petani jual langsung GKP.
Nilai R-C ratio responden petani tunda jual GKP adalah sebesar 1,85, artinya setiap satu rupiah biaya yang dikeluarkan untuk usahatani padi akan menghasilkan penerimaan sebesar Rp 1,85. Nilai R-C rasio untuk responden petani jual langsung GKP adalah sebesar 1,78 artinya setiap satu rupiah biaya yang dikeluarkan untuk usahatani padi menghasilkan penerimaan sebesar Rp 1,78. Nilai R/C petani tunda jual GKP lebih besar dibandingkan nilai R-C petani jual langsung GKP. Hal ini menunjukkan bahwa menunda jual GKP lebih menguntungkan dibandingkan dengan jual langsung GKP setelah panen.

\section{Uji Beda Pendapatan Petani Tunda Jual GKP dan Jual Langsung GKP}

Untuk mengetahui apakah terdapat perbedaan yang signifikan antara pendapatan usahatani petani tunda jual GKP dan jual langsung GKP di Desa Karang Binangu maka digunakan analisa uji beda rata-rata (uji t test) dengan bantuan program Microsoft Exel. Independen T Test adalah uji komparatif atau uji beda untuk mengetahui adakah perbedaan mean atau rerata yang bermakna antara 2 kelompok bebas yang berskala data interval/rasio. Dua kelompok bebas yang dimaksud di sini adalah antara pendapatan petani tunda jual GKP dan jual langsung GKP.

Tabel 9. Perbandingan Rata-rata Pendapatan Petani Tunda Jual GKP dan Jual Langsung

\begin{tabular}{|c|c|c|c|}
\hline No & Komponen & $\begin{array}{c}\text { Tunda Jual } \\
\text { GKP }\end{array}$ & Jual Langsung GKP \\
\hline 1. & Penerimaan ( $\mathrm{Rp} \mathrm{HaMI}$ ) & 23.801 .633 & 21.527 .265 \\
\hline 2. & Biaya Total (Rp HaMI) & 12.875 .604 & 12.107 .847 \\
\hline 3 & Pendapatan (Rp/HaMI) & 10.925 .969 & 9.419 .417 \\
\hline
\end{tabular}

Sumber : Data Primer, 2014. (Lampiran 19 \& 35).

Berdasarkan tabel 9 di atas menunjukkan bahwa dalam melakukan usahatani padi sawah pendapatan yang diperoleh dari responden tunda jual GKP adalah sebesar Rp 10.925.969/Ha/MT dan pendapatan yang diperoleh dari responden jual langsung GKP adalah sebesar Rp 9.419.417/Ha/MT. Rata-rata pendapatan responden tunda jual GKP lebih tinggi daripada pendapatan responden petani jual langsung GKP dengan selisih pendapatan Rp 1.506.552/Ha/MT. Hal ini menunjukkan 
bahwa pelaksanaan menunda jual GKP lebih menguntungkan dibandingkan dengan menjual langsung GKP setelah panen

Berdasarkan hasil analisis uji- $\mathrm{t}$ diperoleh hasil : pada tingkat kepercayaan 95\% dan tingkat error 5\% diperoleh nilai thit $=5,705$ dan nilai t-tabel 2,036 Dengan demikian nilai t-hit > t-tabel, yang artinya bahwa terdapat perbedaan yang signifikan (nyata) antara pendapatan petani tunda jual GKP dengan pendapatan petani jual langsung GKP sehingga dapat dinyatakan tolak Ho dan terima Ha.

\section{KESIMPULAN DAN SARAN}

\section{Kesimpulan}

Berdasarkan hasil perhitungan di atas maka dapat ditarik kesimpulan sebagai berikut :

1. Rata-rata penerimaan yang diterima oleh petani tunda jual GKP adalah sebesar Rp 23.801.633/Ha/MT, biaya produksi sebesar 12.875.664/Ha/MT sehingga diperoleh pendapatan sebesar Rp 10.925.969/Ha/MT. Penerimaan yang diterima oleh petani jual langsung GKP adalah 21.527.265/Ha/MT, biaya produksi sebesar 12.107.847/Ha/MT sehingga diperoleh pendapatan sebesar $\mathrm{Rp} 9.419 .417 / \mathrm{Ha} / \mathrm{MT}$.

2. Rata-rata pendapatan responden tunda jual GKP lebih tinggi daripada pendapatan responden petani jual langsung GKP dengan selisih pendapatan rata-rata $\mathrm{Rp}$ 1.506.552/Ha/MT. Nilai R-C ratio responden petani tunda jual GKP adalah sebesar 1,85, Nilai R-C rasio untuk responden petani jual langsung GKP adalah sebesar 1,78. Hal ini menunjukkan bahwa pelaksanaan menunda jual GKP lebih menguntungkan dibandingkan dengan pelaksanaan jual langsung GKP setelah panen.

3. Secara statistik terdapat perbedaan yang nyata (signifikan) antara pendapatan responden tunda jual GKP dan responden jual langsung GKP. Hal ini dapat dilihat dari nilai $\mathrm{t}$ hitung sebesar 5,705 dan nilai t tabel adalah 2,036. Nilai t hitung > Nilai t tabel sehingga terdapat perbedaan yang signifikan.

\section{B. Saran}

Berdasarkan hasil penelitian dan kesimpulan yang telah dipaparkan, maka dapat dikemukakan saran sebagai berikut :

1. Perlu dilakukan upaya sosialisasi dan penyuluhan oleh pihak terkait kepada petani untuk melakukan tunda jual dan menggalakkan kembali hidupnya lumbung desa.

2. Penerapan tunda jual terbukti dapat meningkatkan pendapatan petani, akan tetapi pada kenyataanya petani masih enggan untuk melakukan tunda jual, hal ini dikarenakan pada saat panen petani harus memperoleh uang cash untuk memenuhi kebutuhan keluarga yang mendesak, oleh karena itu dibutuhkan suatu lembaga pinjaman modal khusus untuk petani padi sawah.

\section{DAFTAR PUSTAKA}

Anonim. 2011. Luas Tanam, Luas Panen dan Produksi Komonditi Padi Sawah dan Padi Ladang. Dinas Tanaman Pangan dan Hortikultura ( TPH ).OKU Timur

Badan Pusat Statistik. 2003. Sensus Pertanian. BPS. Jakarta.

Femina, V. D. 2006. Dampak Kebijakan Harga Gabah Terhadap Produksi Padi di Pulau Jawa. Skripsi. Program Studi Ekonomi Pertanian dan Sumberdaya, Fakultas Pertanian. IPB. Bogor. (Tidak dipublikasikan).

Gunawan. 2004. Analisis Penerapan Sistem Tunda Jual Pola Gadai Gabah terhadap Pendapatan Petani. Tesis. Sekolah Pascasarjana. IPB. Bogor. (Tidak dipublikasikan)

Rachmat, M. 2000. Analisis Nilai Tukar Petani Indonesia. Disertasi. Program Pasca Sarjana. IPB. Bogor. (Tidak dipublikasikan).

Soekartawi. 2003. Analisis Usahatani. UI Press. Jakarta. .2002. Analisis Usaha Tani. UI

Press : Jakarta 
Suryana, A., S. Mardianto dan M. Ikhsan. 2001. Bunga Rampai Ekonomi Beras. Lembaga Penyelidikan Ekonomi dan Masyarakat, Fakultas Ekonomi, Universitas Indonesia. Jakarta.

Yulisa, M. 2008. Efektivitas Penetapan HPP Gabah Terhadap Pendapatan Petani.

(Kasus Kecamatan Binong dan Kecamatan Pusakanagara Kabupaten Subang, Jawa Barat). Skripsi. Program Studi Ekstensi Manajemen Agribisnis, Fakultas Pertanian. IPB. Bogor. (Tidak dipublikasikan). 